Supporting Information for:

\title{
Organic Nanotube with Subnanometer, pH-Responsive Lumen
}

Shawn M. Darnall ${ }^{\ddagger}$, Changyi Li ${ }^{\ddagger}$, Martha Dunbar", Marco Alsina Ting $\mathrm{Xu}^{*},+,+, \delta$

'Department of Materials Science and Engineering, University of California, Berkeley, California 94720-1760, United States

The Molecular Foundry, Lawrence Berkeley National Laboratory, Berkeley, California 94720, United States

'Department of Civil and Environmental Engineering and Mechanical Engineering, Northwestern University, Evanston, Illinois 60208-3111, United States

${ }^{\S}$ Department of Chemistry, University of California, Berkeley, California 94720-1760, United States

Table of Contents

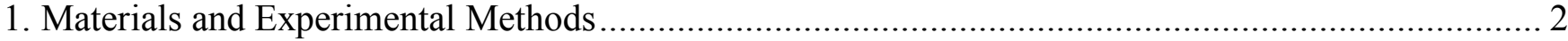

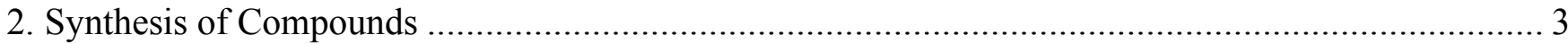

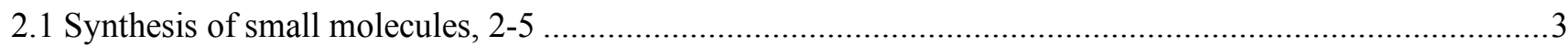

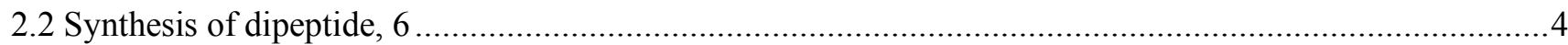

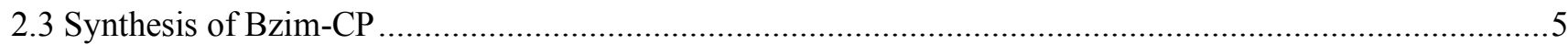

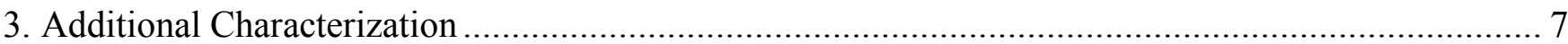

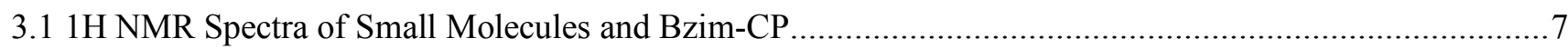

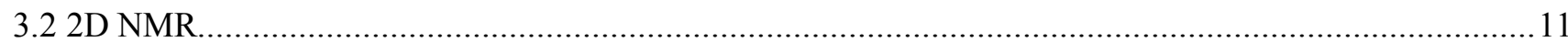

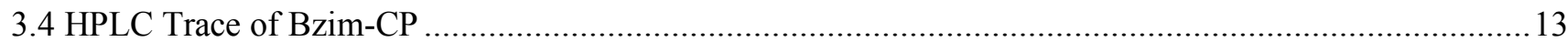

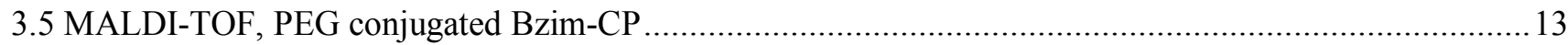

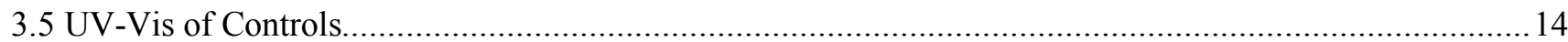

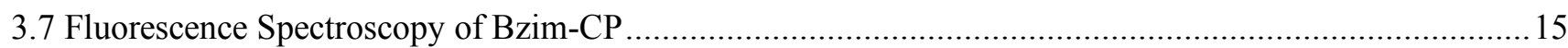

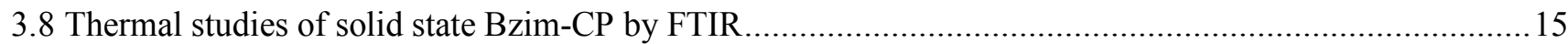

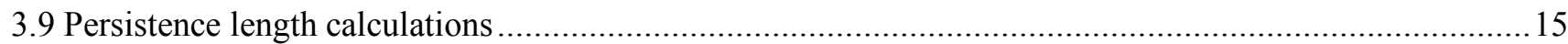

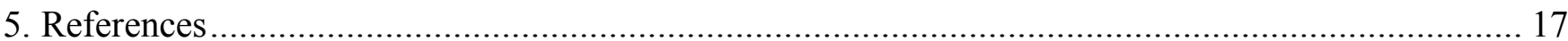




\section{Materials and Experimental Methods}

2-amino-3-nitrobenzoic acid was purchased from Matric Scientific. Thionyl chloride, diisopropylethylamine (DIPEA), 4-methylaminopyridine (DMAP), and Di-tert-butyl dicarbonate were purchased from Sigma-Aldrich. 2-Chlorotrityl resin and Fmoc protected amino acids were purchased EMD Millipore. Dimethylformamide (DMF) and 2-(6-Chloro-1H-benzotriazole-1-yl)-1,1,3,3-tetramethylaminium hexafluorophosphate (HCTU) was purchased from Peptide Solutions, LLC. Piperidine was purchased from Spectrum Scientific. Fmoc-chloride was purchased from Oakwood Chemicals. 2-methyl-3aminobenzoic acid and palladium on carbon was purchased from Tokyo Chemical Industry. NHS-PEG $\mathrm{Mw}=2000 \mathrm{~g} / \mathrm{mol}$ was purchased form Rapp Polymere. All other chemicals and solvents (HPLC grade) were purchased from Fisher Chemical. Every chemical was used as is without further purification.

${ }^{1} \mathbf{H}$ NMR spectra of small molecules were taken on a Bruker Avance $600 \mathrm{MHz}$ Spectrometer using a Z-gradient Triple Broad Band Inverse detection probe. Samples were dissolved in deuterated solvent at concentrations greater than $10 \mathrm{mg} / \mathrm{mL}$ and chemical shifts converted to parts per million relative to the solvent peak. ${ }^{1} \mathrm{H}$ NMR spectra and $2 \mathrm{D}^{1} \mathrm{H}^{1} \mathrm{H}$ NMR (COSY and NOESY) of Bzim-CP were performed in $d_{6}$-DMSO at $10 \mathrm{mg} / \mathrm{mL}$ and measured on a Bruker Avance $500 \mathrm{MHz}$ spectrometer using a Zgradient Triple Broad Band Inverse detection probe. Mass spectrometry was recorded using either the LC-MS system from Agilent equipped with 6230 MS-TOF system or Voyager DE Pro, Matrix Assisted Laser Deposition/Ionization Time of Flight (MALDI-TOF) spectrometer from Applied Biosystems. Peptide Synthesis was done on the Prelude Synthesizer from Protein Technologies using standard 9fluorenylmethyl carbamate (Fmoc) protection chemistry. Atomic Force Microscopy (AFM) images were taken on a Dimension Edge from Bruker. CPN and CPN-PEG samples were dissolved in different solvents of varying concentrations and spun-cast onto a piece of (100) silicon wafer. After the solutions dried, small circular stains remained and images were taken at the outer edges. $200 \mu \mathrm{M}$ solutions of toluene and DMF gave the best images for CPNs. Transmission electron microscopy (TEM) images were taken on a Philips FEI Tecnai TEM operating at $120 \mathrm{kV}$. 200 mesh copper grids (Ted Pella) were placed under oxygen plasma for 2 minutes. $5 \mu \mathrm{L}$ of a $0.25 \mathrm{mg} / \mathrm{mL}$ solution of lyophilized CPN dissolved in acetonitrile was placed onto the grid for $1 \mathrm{~min}$ before being wicked off by filter paper. A negative stain of $2 \%$ phosphotungstic acid solution $(\mathrm{pH} 7$, using $\mathrm{NaOH}$ ) in water was subsequently applied onto the grid for $1 \mathrm{~min}$ and wicked off by filter paper. Circular dichroism measurements were performed on a Jasco J-815. Samples were dissolved in phosphate buffer and placed into either a $1 \mathrm{~cm}$ or 1 $\mathrm{mm}$ cuvette depending on solution concentration. Molar ellipticity was calculated using $[\theta]=\theta /\left(10^{*} C^{*} l\right)$ where $\theta$ is in mDeg, $C$ is in moles/L, $l$ is pathlength in $\mathrm{cm}$. Resulting value has values of deg $\mathrm{cm}^{2} \mathrm{dmol}^{-1}$. In the heating experiments, the cell was raised to the target temperature and held for 5 min before measurements were taken. FT-IR Spectroscopy was performed on a Nicolet 6700 FT-IR Spectrometer from Thermo Scientific. The samples were first dissolved in solvent and then drop-cast onto $\mathrm{a} \mathrm{CaF}_{2}$ plate. The sample was allowed to dry at ambient conditions, and if the resulting signals were weak, additional drops of solution were added. The system was purged with nitrogen throughout the experiments, including 20 minutes prior to taking the first measurement. UV-Vis spectra were taken on an Agilent 8453 spectrophotometer using a $1 \mathrm{~cm}$ path length quartz cuvette. Bzim-CP was dissolved in $10 \mathrm{mM}$ tris buffer at a concentration of $40 \mu \mathrm{M}$. To $200 \mathrm{uL}$ of solution was added minimal volumes of various concentrations of $\mathrm{HCl}$ or $\mathrm{NaOH}$. Acidic and basic conditions were tested separately on identical solutions. After each addition, the $\mathrm{pH}$ was measured using an Accumet $\mathrm{AB}-15 \mathrm{pH}$ meter and the signal was corrected for changes in volume. Fluorescence spectroscopy was performed using a PerkinElmer LS-55 fluorescence spectrometer. The sample, $10 \mu \mathrm{M}$ Bzim-CP in water, was loaded into a 1-cm path-length quartz 
cell (Starna Cells). The sample was excited at $260 \mathrm{~nm}$ (slit size: $7 \mathrm{~nm}$ ), and the emission was monitored using a slit size of $7 \mathrm{~nm}$ at rate of $200 \mathrm{~nm} / \mathrm{min}$. $1 \mathrm{M} \mathrm{HCl}$ and $5 \mathrm{M} \mathrm{NaOH}$ were used to adjust the $\mathrm{pH}$.

\section{Synthesis of Compounds}

\subsection{Synthesis of small molecules, 2-5}

Synthesis of small molecule, 2. Concentrated sulfuric acid (28 mL) was added dropwise to a solution of 1 (2-amino-3-nitrobenzoic acid, $40.0 \mathrm{~g}, 0.220 \mathrm{~mol})$ in ethanol $(400 \mathrm{~mL})$, and the reaction mixture was allowed to reflux for three days. The product was precipitated by adding the solution to a mixture of ice and $2 \mathrm{M} \mathrm{NaOH}$ and subsequently filtered. The collected material was re-dissolved in ethanol and recovered by recrystallization. The resulting crystals were orange-yellow needles with a high aspect ratio. (28.7 g, $0.137 \mathrm{~mol}, 62.2 \%$ yield).

${ }^{1} \mathbf{H}$ NMR $\left(\mathrm{CDCl}_{3}, 600 \mathrm{MHz}\right.$, residual internal $\left.\mathrm{CHCl}_{3} \delta 7.26\right) \delta(\mathrm{ppm}) 8.47$ (s, broad, $\left.2 \mathrm{H}\right), 8.37(\mathrm{dd}, J=$ 8.4, 1.7 Hz, 1H), 8.25 (dd, $J=7.7,1.7 \mathrm{~Hz}, 1 \mathrm{H}), 6.64(\mathrm{dd}, J=8.4,7.7 \mathrm{~Hz}, 1 \mathrm{H}), 4.37(\mathrm{q}, J=7.1 \mathrm{~Hz}, 2 \mathrm{H})$, $1.40(\mathrm{t}, J=7.1 \mathrm{~Hz}, 3 \mathrm{H})$.

${ }^{13} \mathbf{C}$ NMR (151 $\mathrm{MHz}, \mathrm{CDCl}_{3}$, Internal Residual $\mathrm{CHCl}_{3}$ 77.16(t)) $\delta$ 167.15, 147.48, 139.43, 133.35, 132.26, 114.85, 114.03, 61.46, 14.36 .

Exact Mass: 210.0641

Found (m/z): $211.0721[\mathrm{M}+\mathrm{H}]^{+}$

Calculated (m/z): $211.0713[\mathrm{M}+\mathrm{H}]^{+}$

Note: Sample was not stable under LC-MS and HR-MS test conditions (mobile phases tested: isopropyl alcohol, acetonitrile, $\mathrm{MeOH}$, and water with and without formic acid, or mixtures with them). Traces of the correct mass was detected in some of the peaks. NMR results, however, are in-line with the structure and it being of high purity.

Synthesis of small molecule, 3. $576 \mathrm{~mL}$ of toluene was used to dissolve 2 (35.9 g, $0.171 \mathrm{~mol})$. To this mixture was added di-tert-butyl dicarbonate $(90.0 \mathrm{~g}, 0.412$ moles $)$ and DMAP (2.7 g, $0.022 \mathrm{~mol})$. The reaction was heated to $75^{\circ} \mathrm{C}$ and stirred overnight. The solution was then allowed to cool and concentrated in vacuo. Excess ethyl acetate was added and then washed with water. The product was dried over sodium sulfate and concentrated in vacuo. Purified material (off-white/yellow opaque rectangular crystals) were recovered by recrystallization in ethyl acetate with pentane diffusion $(51.7 \mathrm{~g}, 0.126 \mathrm{~mol}$, $73.8 \%$ yield).

${ }^{1} \mathbf{H}$ NMR $\left(\mathrm{CDCl}_{3}, 600 \mathrm{MHz}\right.$, residual internal $\left.\mathrm{CHCl}_{3} \delta 7.26\right) \delta(\mathrm{ppm}) 8.19(\mathrm{dd}, J=7.9,1.6 \mathrm{~Hz}, 1 \mathrm{H})$, $8.06(\mathrm{dd}, J=8.1,1.6 \mathrm{~Hz}, 1 \mathrm{H}), 7.56(\mathrm{t}, J=8.0 \mathrm{~Hz}, 1 \mathrm{H}), 4.37(\mathrm{q}, J=7.1 \mathrm{~Hz}, 2 \mathrm{H}), 1.38(\mathrm{t}, J=7.1 \mathrm{~Hz}, 3 \mathrm{H})$, $1.36(\mathrm{~s}, 18 \mathrm{H})$.

${ }^{13} \mathrm{C}$ NMR $\left(151 \mathrm{MHz}, \mathrm{CDCl}_{3}\right.$, residual internal $\left.\mathrm{CHCl}_{3} \delta 77.16(\mathrm{p})\right) \delta 164.46,149.45,147.74,135.05$, $132.64,131.76,128.57,127.79,83.60,62.43,27.83,14.30$.

Exact Mass: 410.1689

Found (m/z): $411.1754[\mathrm{M}+\mathrm{H}]^{+}$(weak signal), $433.1574[\mathrm{M}+\mathrm{Na}]^{+}, 843.3254[2 \mathrm{M}+\mathrm{Na}]^{+}$

Calculated (m/z): $411.1761[\mathrm{M}+\mathrm{H}]^{+}, 433.1581[\mathrm{M}+\mathrm{Na}]^{+}, 843.3270[2 \mathrm{M}+\mathrm{Na}]^{+}$ 
Synthesis of small molecule, 4.3 (30.7 g, $0.0748 \mathrm{~mol})$ was dissolved in minimal ethanol and $56 \mathrm{~mL}$ of $2 \mathrm{M} \mathrm{NaOH}$ solution was added. After stirring for 2 days, the mixture was partially concentrated in vacuum to remove ethanol. After the addition of ethyl acetate, the solution was carefully acidified with $2 \mathrm{M}$ $\mathrm{HCl}$ followed by citric acid. The organic layer was washed with water three times, and then dried with sodium sulfate. The sample was concentrated in vacuo and recovered by recrystallization in an ethyl acetate/pentane (diffusion) mixture ( $19.4 \mathrm{~g}, .0509 \mathrm{~mol}, 68.0 \%$ yield).

${ }^{1} \mathbf{H}$ NMR $\left(600 \mathrm{MHz}, \mathrm{CD}_{3} \mathrm{OD}\right.$, residual internal $\left.\mathrm{CHD}_{2} \mathrm{OD} \delta 3.31\right) \delta 8.27(\mathrm{dd}, J=7.8,1.6 \mathrm{~Hz}, 1 \mathrm{H}), 8.16$ (dd, $J=8.1,1.6 \mathrm{~Hz}, 1 \mathrm{H}), 7.69(\mathrm{t}, J=8.0 \mathrm{~Hz}, 1 \mathrm{H}), 1.32(\mathrm{~s}, 18 \mathrm{H})$.

${ }^{13} \mathrm{C}$ NMR $\left(151 \mathrm{MHz}, \mathrm{CD}_{3} \mathrm{OD}\right.$, residual internal $\left.\mathrm{CHD}_{2} \mathrm{OD} \delta 49.00 \mathrm{ppm}\right) \delta 166.77,150.90,149.01$, 136.06, 133.27, 132.71, 130.26, 128.77, 84.73, 49.01, 27.85.

Exact Mass: 382.1376

Found (m/z): $383.1431[\mathrm{M}+\mathrm{H}]^{+}$(weak signal), $405.1262[\mathrm{M}+\mathrm{Na}]^{+}, 787.2630[2 \mathrm{M}+\mathrm{Na}]^{+}$

Calculated (m/z): $383.1448[\mathrm{M}+\mathrm{H}]^{+}, 405.1268[\mathrm{M}+\mathrm{Na}]^{+}, 787.2644[2 \mathrm{M}+\mathrm{Na}]^{+}$

Synthesis of small molecule, 5.4 (4.0 g, $0.010 \mathrm{~mol})$ was placed in a round bottom flask with 5\% Pd/C $(400 \mathrm{mg})$. The system was put under vacuum, and hydrogen gas and ethanol were added to hydrogenate the material. After completion, the solution was filtered using Celite and paper filters followed by concentration in vacuo. The product was an off-white powder (3.1 g, $8.8 \mathrm{mmol}, 84 \%)$.

${ }^{1} \mathbf{H}$ NMR $\left(600 \mathrm{MHz}, \mathrm{CD}_{3} \mathrm{OD}\right.$, residual internal $\left.\mathrm{CHD}_{2} \mathrm{OD} \delta 3.31 \mathrm{ppm}\right) \delta(\mathrm{ppm}) 7.28(\mathrm{dd}, J=7.7,1.5 \mathrm{~Hz}$, $1 \mathrm{H}), 7.13(\mathrm{t}, J=7.9 \mathrm{~Hz}, 1 \mathrm{H}), 6.97(\mathrm{dd}, J=8.1,1.5 \mathrm{~Hz}, 1 \mathrm{H}), 1.34(\mathrm{~s}, 18 \mathrm{H})$.

${ }^{13} \mathrm{C}$ NMR (151 MHz, $\mathrm{CD}_{3} \mathrm{OD}$, residual internal $\left.\mathrm{CHD}_{2} \mathrm{OD} \delta 49.00 \mathrm{ppm}\right) \delta$ (ppm) 169.27, 152.76, 146.43, 129.71, 129.05, 125.80, 120.83, 120.72, 83.41, 28.01.

Exact Mass: 352.1634

Found (m/z): $353.1723[\mathrm{M}+\mathrm{H}]^{+}$(weak signal), $375.1535[\mathrm{M}+\mathrm{Na}]^{+}, 605.2829[2 \mathrm{M}-\mathrm{Boc}+2 \mathrm{H}]^{+}$, $727.3183[2 \mathrm{M}+\mathrm{Na}]^{+}$

Calculated (m/z): $353.1706[\mathrm{M}+\mathrm{H}]^{+}, 375.1526[\mathrm{M}+\mathrm{Na}]^{+}, 605.2817[2 \mathrm{M}-\mathrm{Boc}+2 \mathrm{H}]^{+}$, $727.3161[2 \mathrm{M}+\mathrm{Na}]^{+}$

\subsection{Synthesis of dipeptide, 6}

$35 \mathrm{~mL}$ of DCM was added to Fmoc-D-Ala-OH (2.0 g, $6.4 \mathrm{mmol})$, followed by $5 \mathrm{~mL}$ of thionyl chloride. As the reaction proceeded, the solid amino acid dissolved into solution, giving the solution a pale yellow color. Once everything had gone into solution, the mixture was stirred for an additional $2 \mathrm{~h}$ and then dried in vacuo. The material was then re-dissolved in DCM and then dried in vacuo, and this step was repeated another 3 times to remove excess thionyl chloride. Fmoc-D-Ala-Cl was obtained as an offwhite powder, $(2.1 \mathrm{~g}, 99 \%)$.

${ }^{1} \mathbf{H}$ NMR $\left(600 \mathrm{MHz}\right.$, residual internal $\left.\mathrm{CHCl}_{3} \delta 7.26 \mathrm{ppm}\right) \delta(\mathrm{ppm}) 7.78(\mathrm{~d}, J=7.6 \mathrm{~Hz}, 2 \mathrm{H}), 7.60(\mathrm{t}, J=$ $7.6 \mathrm{~Hz}, 2 \mathrm{H}), 7.42(\mathrm{t}, J=7.4 \mathrm{~Hz}, 2 \mathrm{H}), 7.33(\mathrm{t}, J=7.5 \mathrm{~Hz}, 2 \mathrm{H}), 5.38(\mathrm{~d}, J=7.9 \mathrm{~Hz}, 1 \mathrm{H}), 4.62(\mathrm{p}, J=7.5$ $\mathrm{Hz}, 1 \mathrm{H}), 4.51(\mathrm{dd}, J=10.7,6.7 \mathrm{~Hz}, 1 \mathrm{H}), 4.42(\mathrm{dd}, J=10.7,7.0 \mathrm{~Hz}, 1 \mathrm{H}), 4.23(\mathrm{t}, J=6.7 \mathrm{~Hz}, 1 \mathrm{H}), 1.59-$ $1.41(\mathrm{~m}, 3 \mathrm{H})$.

${ }^{13} \mathbf{C}$ NMR $\left(151 \mathrm{MHz}, \mathrm{CDCl}_{3}\right.$, residual internal $\left.\mathrm{CHCl}_{3} \delta 77.16\right) \delta 175.61,155.61,143.68,141.42,127.90$, 127.21, 125.06, 120.14, 77.37, 77.16, 76.95, 67.44, 58.77, 47.21, 17.29.

Fmoc-D-Ala-Cl $(1.7 \mathrm{~g}, 5.1 \mathrm{mmol})$ was then added to a solution of $5(1.0 \mathrm{~g}, 2.8 \mathrm{mmol})$ in $15 \mathrm{~mL}$ DCM and $5 \mathrm{~mL}$ pyridine at $40^{\circ} \mathrm{C}$ for $30 \mathrm{~min}$, resulting in the formation of the Fmoc protected dipeptide. The reaction mixture was then concentrated in vacuo and redissolved in ethyl acetate. The solution was then 
washed three times with aqueous copper sulfate solution to remove pyridine, followed by three washes of aqueous ethylenediaminetetraacetic acid to remove excess copper. The organic layer was then dried with sodium sulfate. TLC, analytical HPLC, and LC-MS showed three main compounds, namely being both starting materials as well as the desired product. Column chromatography (6\% methanol in dichloromethane) was used to separate out the dipeptide $(1.1 \mathrm{~g}, 1.7 \mathrm{mmol}, 61 \%)$.

${ }^{1} \mathrm{H}$ NMR $\left(600 \mathrm{MHz}, \mathrm{CD}_{3} \mathrm{OD}\right.$, residual internal $\left.\mathrm{CHD}_{2} \mathrm{OD} \delta 3.31 \mathrm{ppm}\right) \delta(\mathrm{ppm}) 8.04(\mathrm{~d}, J=8.2 \mathrm{~Hz}, 1 \mathrm{H})$, $7.81(\mathrm{~d}, J=6.9 \mathrm{~Hz}, 1 \mathrm{H}), 7.79(\mathrm{~d}, J=7.7 \mathrm{~Hz}, 2 \mathrm{H}), 7.73(\mathrm{t}, J=8.8 \mathrm{~Hz}, 2 \mathrm{H}), 7.66-7.59(\mathrm{~m}, 0 \mathrm{H}), 7.43(\mathrm{t}$, $J=7.9 \mathrm{~Hz}, 1 \mathrm{H}), 7.38(\mathrm{t}, J=7.5 \mathrm{~Hz}, 2 \mathrm{H}), 7.31(\mathrm{t}, J=7.6 \mathrm{~Hz}, 2 \mathrm{H}), 4.50-4.32(\mathrm{~m}, 3 \mathrm{H}), 4.26(\mathrm{t}, J=6.9$ $\mathrm{Hz}, 1 \mathrm{H}), 1.41(\mathrm{~d}, J=7.2 \mathrm{~Hz}, 3 \mathrm{H}), 1.35-1.24(\mathrm{~m}, 18 \mathrm{H})$.

${ }^{13} \mathrm{C}$ NMR (151 MHz, CD ${ }_{3} \mathrm{OD}$, residual internal $\left.\mathrm{CHD}_{2} \mathrm{OD} \delta 49 \mathrm{ppm}\right) \delta(\mathrm{ppm}) 173.90,158.94,151.88$, $151.68,145.51,145.22,142.60,142.57,136.70,128.92,128.85,128.73,128.71,128.12,126.40,126.35$, $120.85,83.99,83.88,68.40,52.31,49.43,49.28,49.14,49.00,48.86,48.72,48.57,48.40,28.06,27.99$, 17.48 .

Exact Mass: $645.2686[\mathrm{M}]$

Found (m/z): $668.2591[\mathrm{M}+\mathrm{Na}]^{+}, 1313.5295[2 \mathrm{M}+\mathrm{Na}]^{+}, 546.2243[\mathrm{M}-\mathrm{Boc}+2 \mathrm{H}]^{+}$, $446.1718[\mathrm{M}-2 \mathrm{Boc}+2 \mathrm{H}]^{+}$

Calculated (m/z): $668.2578[\mathrm{M}+\mathrm{Na}]^{+}, 1313.5265[2 \mathrm{M}+\mathrm{Na}]^{+}, 546.2234[\mathrm{M}-\mathrm{Boc}+2 \mathrm{H}]^{+}$, $446.1710[\mathrm{M}-2 \mathrm{Boc}+2 \mathrm{H}]^{+}$

\subsection{Synthesis of Bzim-CP}

Initial amino acid attachment: 2-chlorotrityl resin was swelled in DCM for 30 min and then loaded with Fmoc-D-Lys(Boc)-OH using a solution of the amino acid and DIPEA in DCM. After $2 \mathrm{~h}$, the resin was filtered and washed and then the reaction was quenched by adding a solution of 5\% methanol in DCM and letting it react for an additional hour. After drying the resin, the loading on the resin was determined by taking approximately $2 \mathrm{mg}$ of resin and deprotecting it in $3 \mathrm{~mL}$ of $20 \%$ piperidine. After 30 min, the solution was diluted and absorbance at $290 \mathrm{~nm}$ was measured. Loading was calculated as Loading $=\operatorname{abs} 290 *$ dilution factor/ $1.65 /$ mass of resin, with units of $\mu$ moles $/ \mathrm{mg}$.

Linear peptide: Reaction vessels were filled with $50 \mu \mathrm{mol}$ worth of amino acid-loaded resin and then loaded onto a Prelude Peptide Synthesizer. After swelling for 30 minutes in DMF, the resin was deprotected using 20\% piperidine in DMF, followed by washing with DMF. The next 5 amino acids were then added using an automated process. Each step consisted of an "Addition phase" where Fmoc protected amino acid ( 5 eq), HCTU (5 eq.), and DIPEA (5 eq.) were added sequentially and mixed for 20 min using nitrogen (and then repeated once more with fresh solution) and a separate "deprotection phase" using 20\% piperidine in DMF. 5 DMF washes were done after each phase. Afterwards, $2 \mathrm{~mL}$ of a DMF solution containing dipeptide (4 eq.), PyBOP (4 eq.) and DIPEA (8 eq.) were added to each reaction vessel and the mixture was reacted for $3 \mathrm{~h}$. Completion was checked using the Kaiser test and the final coupling step was repeated if necessary. The peptide was cleaved using $1 \%$ trifluoroacetic acid (TFA) in DCM for $45 \mathrm{~min}$. The solution was then concentrated in vacuo and then precipitated with diethyl ether.

It is worth noting that the position of the dipeptide in the sequence greatly affects the yield and purity. Inserting it at the beginning of the sequence results in the growing peptide cleaving itself from the resin. Inserting the peptide in the middle of the sequence resulted in unidentifiable side products. By attaching the dipeptide at the end of the linear sequence, a higher yield was obtained with very few side products as detected by LC-MS. 
Exact Mass: 1205.6907 [M]

Calculated (m/z): $1206.6979[\mathrm{M}+\mathrm{H}]^{+}, 1228.6799[\mathrm{M}+\mathrm{Na}]^{+}, \quad 1250.6619[\mathrm{M}-\mathrm{H}+2 \mathrm{Na}]^{+}$

Found (m/z): $\quad 1206.7002[\mathrm{M}+\mathrm{H}]^{+}, 1228.6834[\mathrm{M}+\mathrm{Na}]^{+}, \quad 1250.6639[\mathrm{M}-\mathrm{H}+2 \mathrm{Na}]^{+}$

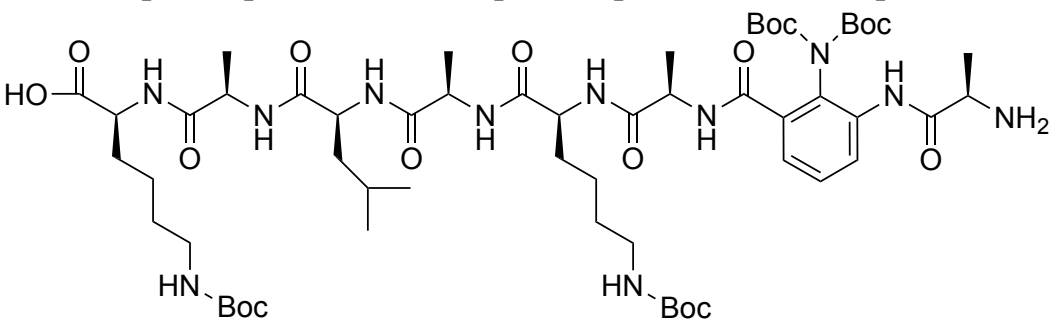

Figure S1 Standard Fmoc peptide synthesis using HCTU as the coupling agent was used to make a linear peptide, $\mathrm{H}_{2} \mathrm{~N}-6-\mathrm{D}-$ Ala-L-Lys-D-Ala-L-Leu-D-Ala-L-Lys-OH.

Cyclized peptide: The linear peptide was dissolved in anhydrous DMF $(1 \mathrm{mM})$ and cooled to $0{ }^{\circ} \mathrm{C}$ before slowly adding a $10 \mathrm{~mL}$ solution of 1-[bis(dimethylamino)methylene]-1H-1,2,3-triazolo[4,5b]pyridinium-3-oxide hexafluorophosphate (HATU) $(1 \mathrm{eq})$ and DIPEA (2 eq). After $2 \mathrm{~h}$, an additional 0.25 and 0.5 equivalents were added, respectively, and stirred for $2 \mathrm{~h}$. Afterwards, the solution was dried in vacuo and Boc protecting groups were cleaved using a 95\% TFA, 2.5\% triisopropylsilane, 2.5\% water at $60^{\circ} \mathrm{C}$ for $3 \mathrm{~h}$. The resulting cyclized and deprotected peptide was precipitated in diethyl ether and purified by preparative HPLC on a Vydac C18 column on a Beckman Coulter RP-HPLC system run from $10-20 \%$ Acetonitrile $(0.1 \%$ TFA) at $8 \mathrm{~mL} /$ minute over $30 \mathrm{~min}$. Collected samples were frozen and lyophilized, resulting in a fluffy, white material. Yield for peptide synthesis of a $300 \mu \mathrm{mol}$ batch was 41 $\mathrm{mg},(18 \%)$.

Exact mass: $769.4599 \mathrm{Da}$

Found (m/z): $770.4697[\mathrm{M}+\mathrm{H}]^{+}, 792.4502[\mathrm{M}+\mathrm{Na}]^{+}, 385.7377[\mathrm{M}+2 \mathrm{H}]^{2+}, 257.4940[\mathrm{M}+3 \mathrm{H}]^{3+}$

Calculated (m/z): $770.4671[\mathrm{M}+\mathrm{H}]^{+}, 792.4491[\mathrm{M}+\mathrm{Na}]^{+}, 385.7372[\mathrm{M}+2 \mathrm{H}]^{2+}, 257.4938[\mathrm{M}+3 \mathrm{H}]^{3+}$

PEG-Conjugated Bzim-CP: Bzim-CP was dissolved in anhydrous DMF at a concentration of 5 $\mathrm{mg} / \mathrm{mL}$. After sonication and stirring for several minutes, 6 eq. of DIPEA was added, followed by 3 eq. of NHS-PEG. The reaction was allowed to mix for 2 days before being dried in vacuo. Crude Bzim-CP2PEG was dissolved in $0.1 \%$ TFA in $\mathrm{H}_{2} \mathrm{O}$ at concentrations of $10 \mathrm{mg} / \mathrm{mL} .500 \mu \mathrm{L}$ was injected into a Beckman Coulter Reverse-Phase High-Pressure Liquid Chromatography system using a C4 column (Vydac $22 \mathrm{~mm} \times 250 \mathrm{~mm}$ ) at a flow rate of $8 \mathrm{~mL} \mathrm{~min}^{-1}$. A linear AB gradient, where solvent A consisted of water containing $0.1 \%(\mathrm{v} / \mathrm{v})$ TFA and solvent B consisted of acetonitrile (ACN) containing $0.1 \%$ $(v / v)$ TFA was used. Conjugates were eluted with a gradient of 20 to $65 \% \mathrm{~B}$ over 45 min and the elution was monitored using a diode array detector at wavelengths of $200 \mathrm{~nm}$ and $220 \mathrm{~nm}$. 


\section{Additional Characterization}

\subsection{H NMR Spectra of Small Molecules and Bzim-CP}

$\underline{\text { Figure S2. }{ }^{1} \mathrm{H} \text { NMR Spectrum of small molecule, 2, in } \mathrm{CDCl} 3}$

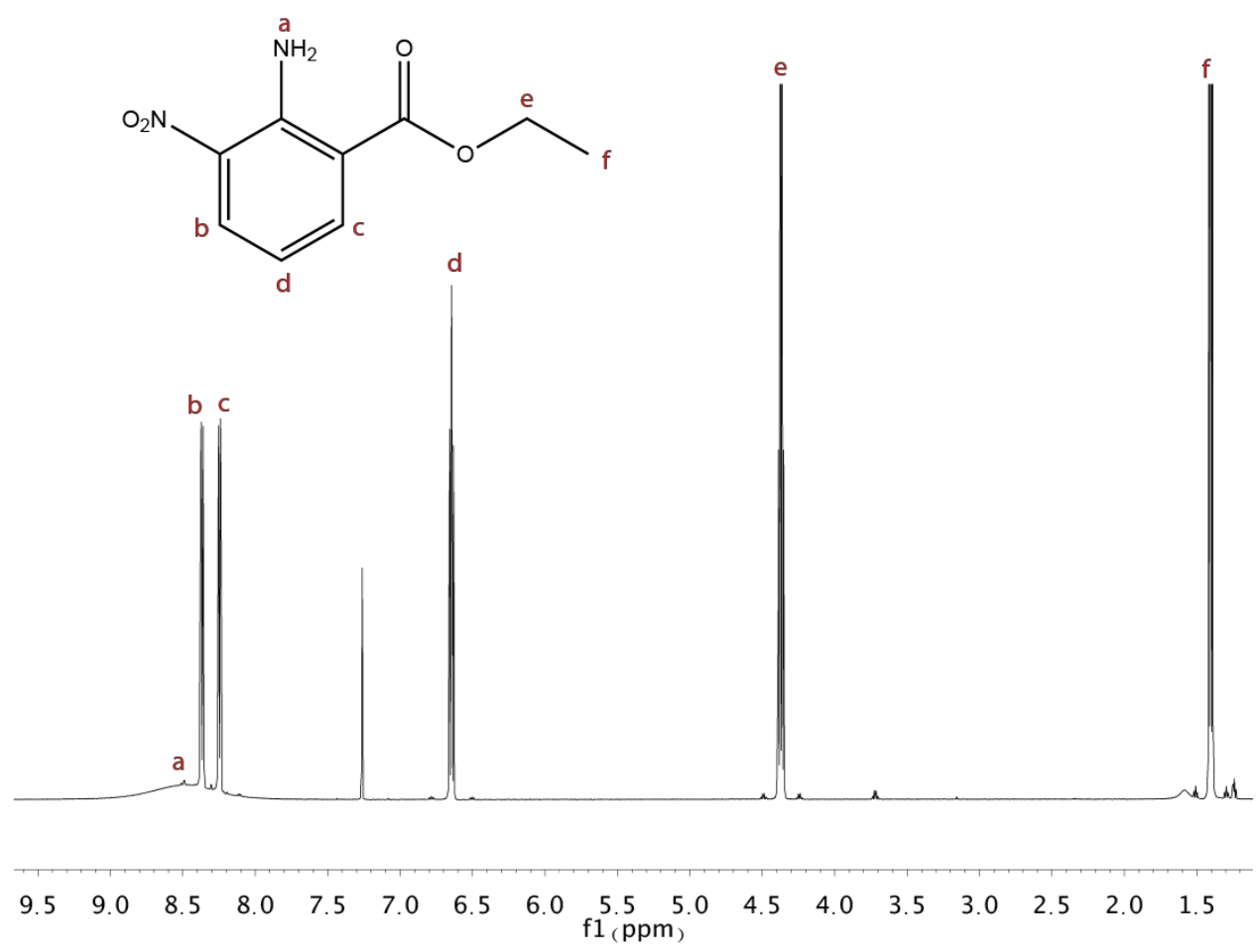


Figure S3. ${ }^{1} \mathrm{H}$ NMR Spectrum of small molecule, 3 , in $\mathrm{CDCl} 3$

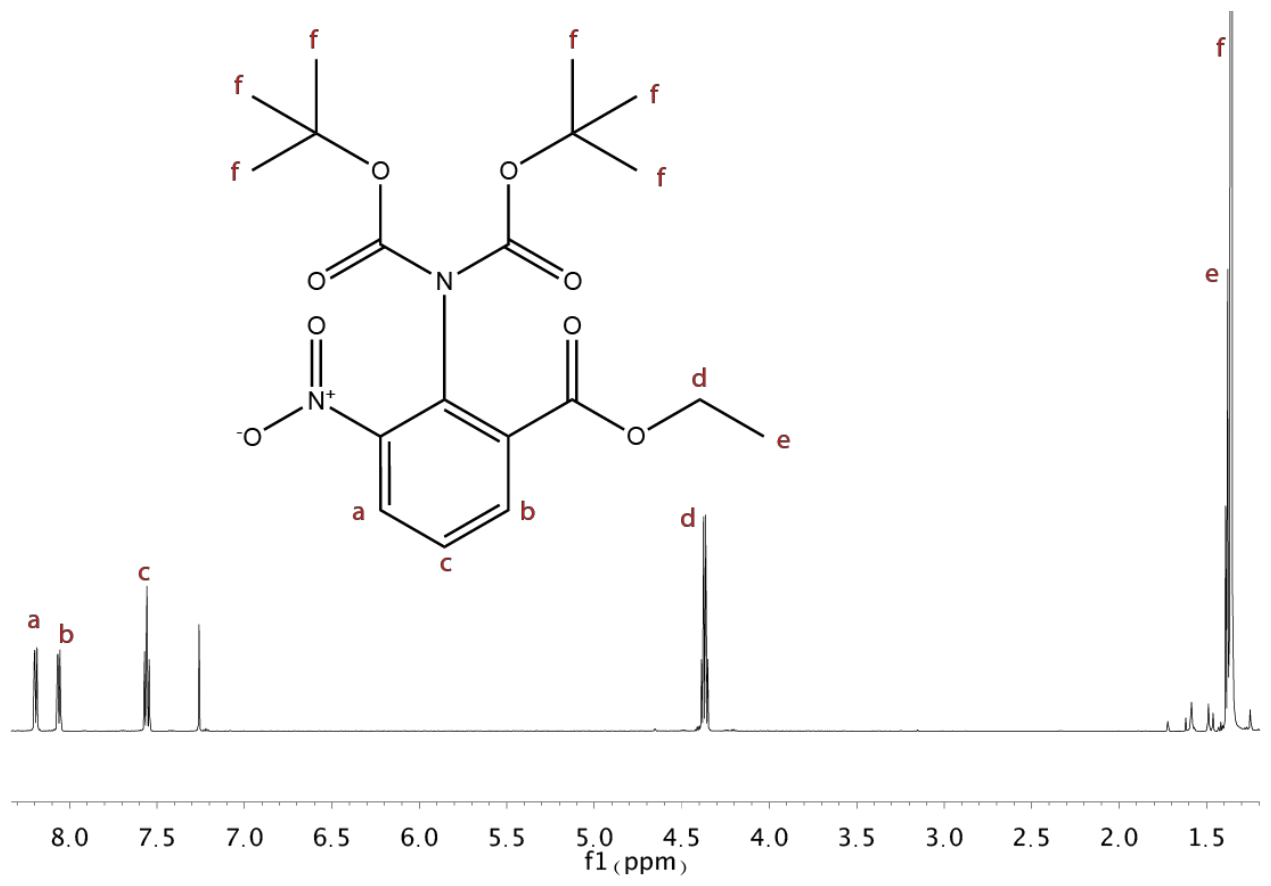

Figure S4. ${ }^{1} \mathrm{H}$ NMR Spectrum of small molecule, 4 , in $\mathrm{CD}_{3} \underline{\mathrm{OD}}$

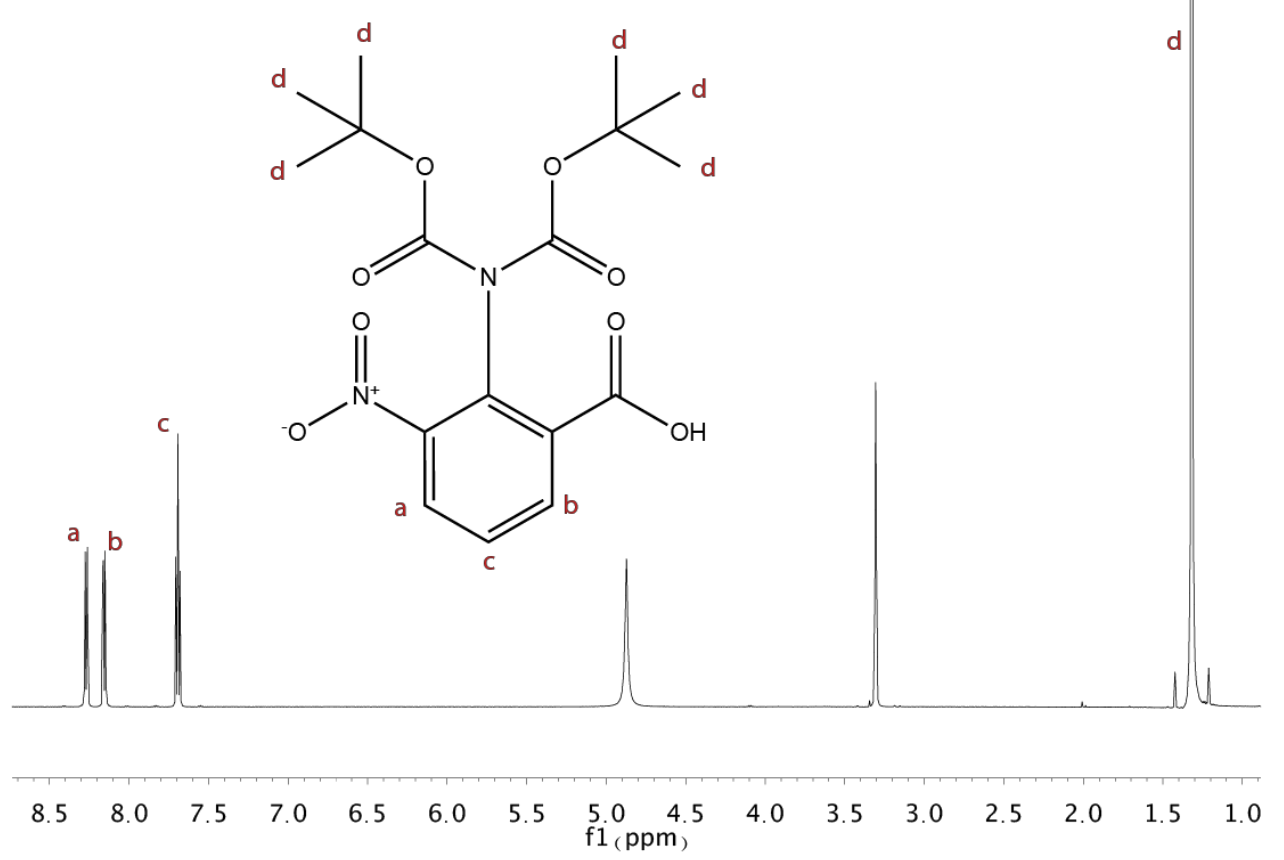


Figure S5. ${ }^{1} \mathrm{H}$ NMR Spectrum of small molecule, 5 , in $\mathrm{CD}_{3} \underline{\mathrm{OD}}$<smiles>Nc1cccc(C(=O)O)c1N(C(=O)OC(Cl)(Cl)Cl)C(=O)OC(Cl)(Cl)Cl</smiles>

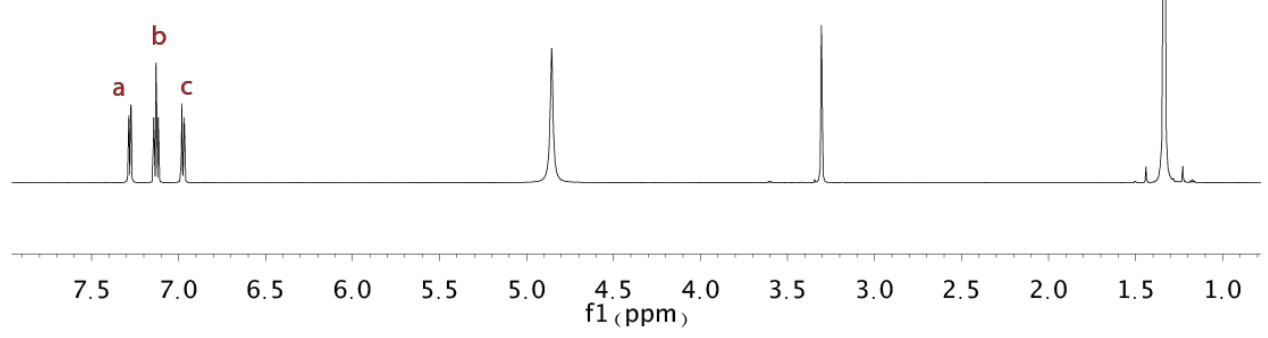

Figure S6. ${ }^{1} \mathrm{H}$ NMR Spectrum of dipeptide, 6, in $\mathrm{CD}_{3} \underline{\underline{\mathrm{OD}}}$

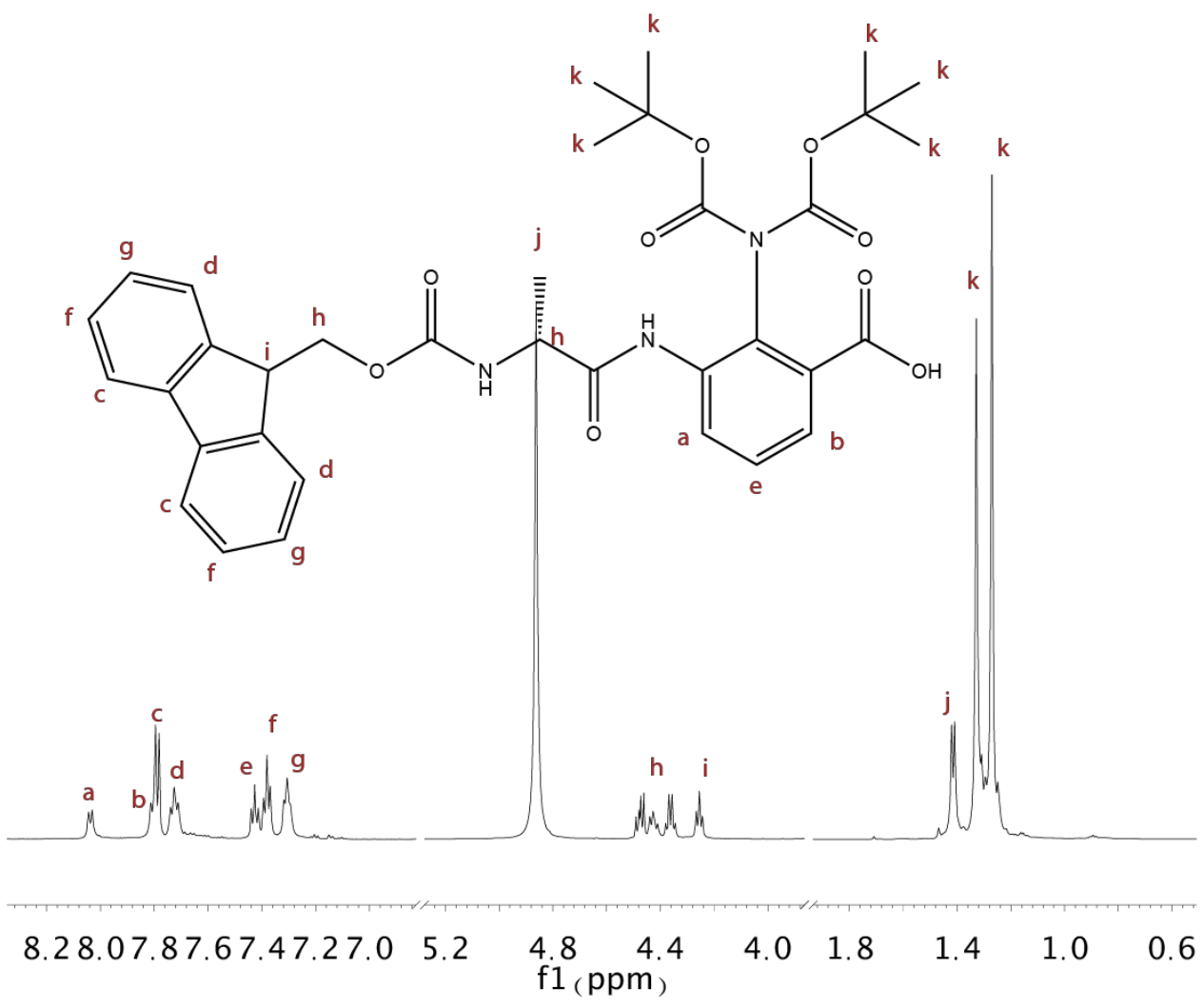




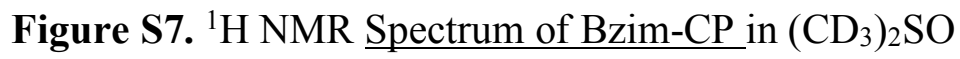

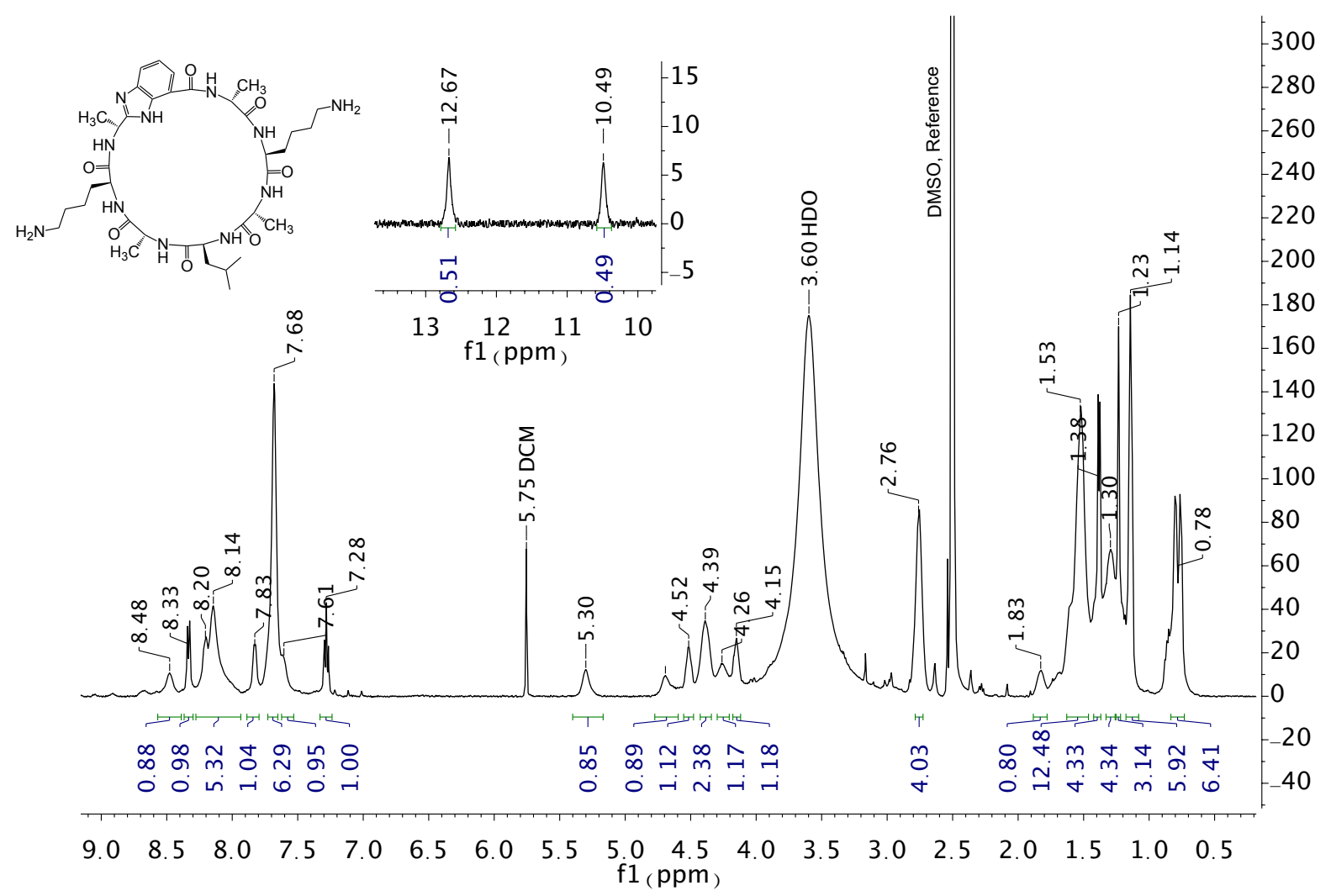

The peaks at integrations at $10.49 \mathrm{ppm}$ and $12.67 \mathrm{ppm}$ are from the benzimidazole group and are each integrated to roughly half a proton in the one-dimensional ${ }^{1} \mathrm{H}$ NMR spectra. This measurement suggests that half of the time, the pros-nitrogen is protonated or the tele-nitrogen is.

Peaks between 7 and 9 ppm correspond to Amide NH, Lys-NH, and aromatic protons. Peaks between 4 and 5.5 correspond to $\alpha$-carbon protons in the backbone. Peaks between 0.5 -at 3.0 correspond to side chain $\mathrm{CH}_{2}$ and $\mathrm{CH}_{3}$ protons. 
Figure S8. ${ }^{1} \mathrm{H}{ }^{1} \mathrm{H}$ 2D NMR, $\mathrm{C}_{2} \mathrm{D}_{6} \mathrm{SO}, 500 \mathrm{MHz}, \mathrm{COSY}$ of Bzim-CP

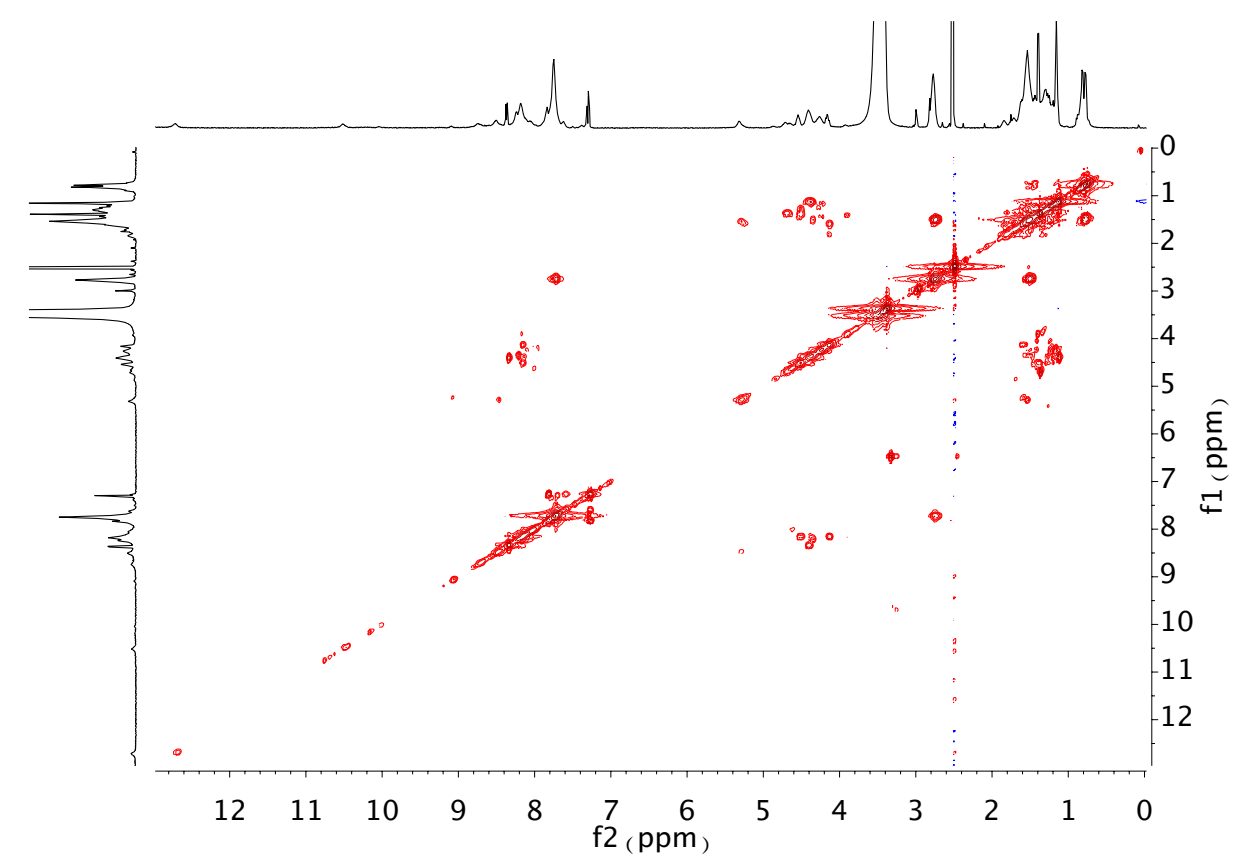

Figure S9 ${ }^{1} \mathrm{H}{ }^{1} \mathrm{H} 2 \mathrm{D}$ NMR, $\mathrm{C}_{2} \mathrm{D}_{6} \mathrm{SO}, 500 \mathrm{MHz}$, NOESY of Bzim-CP

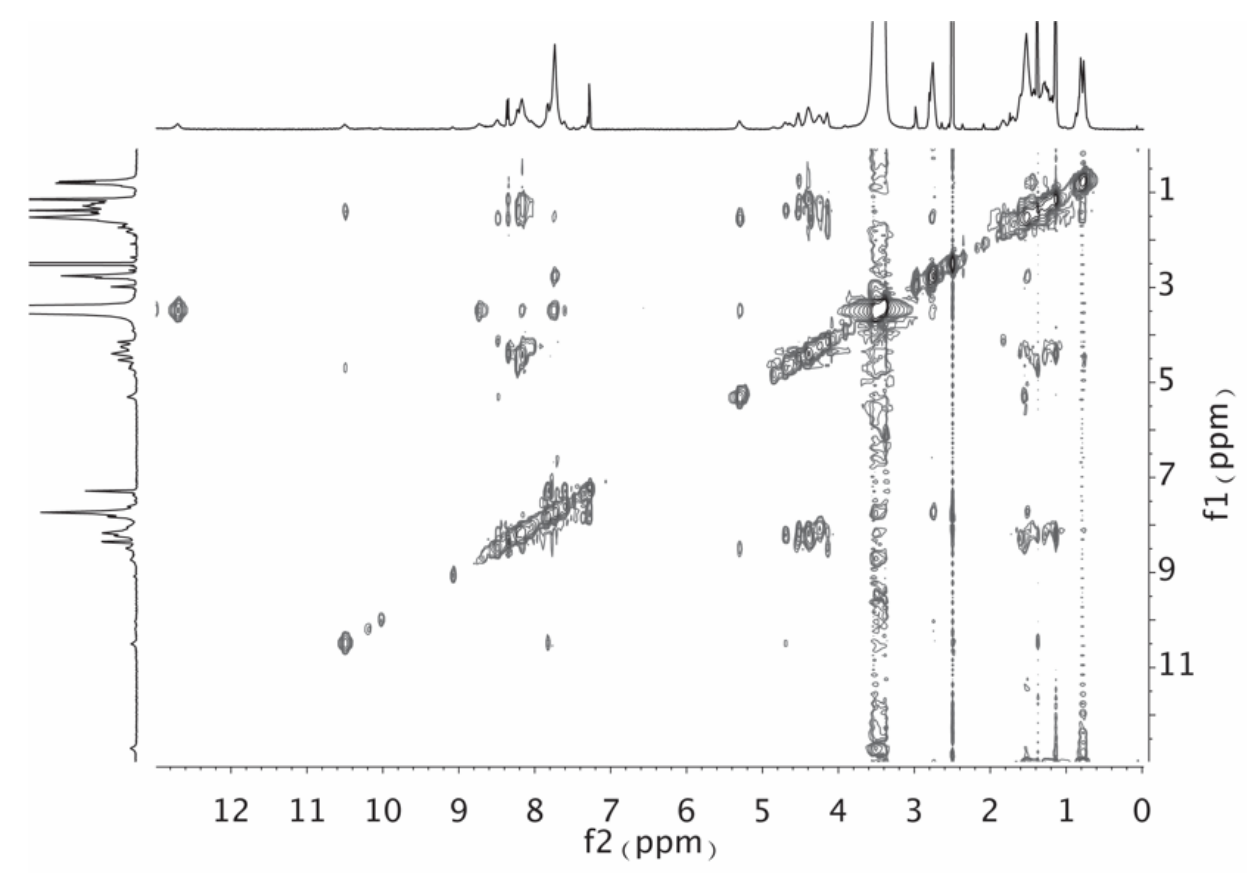


Figure S10. Identification of pros- and tele-nitrogens using NOESY

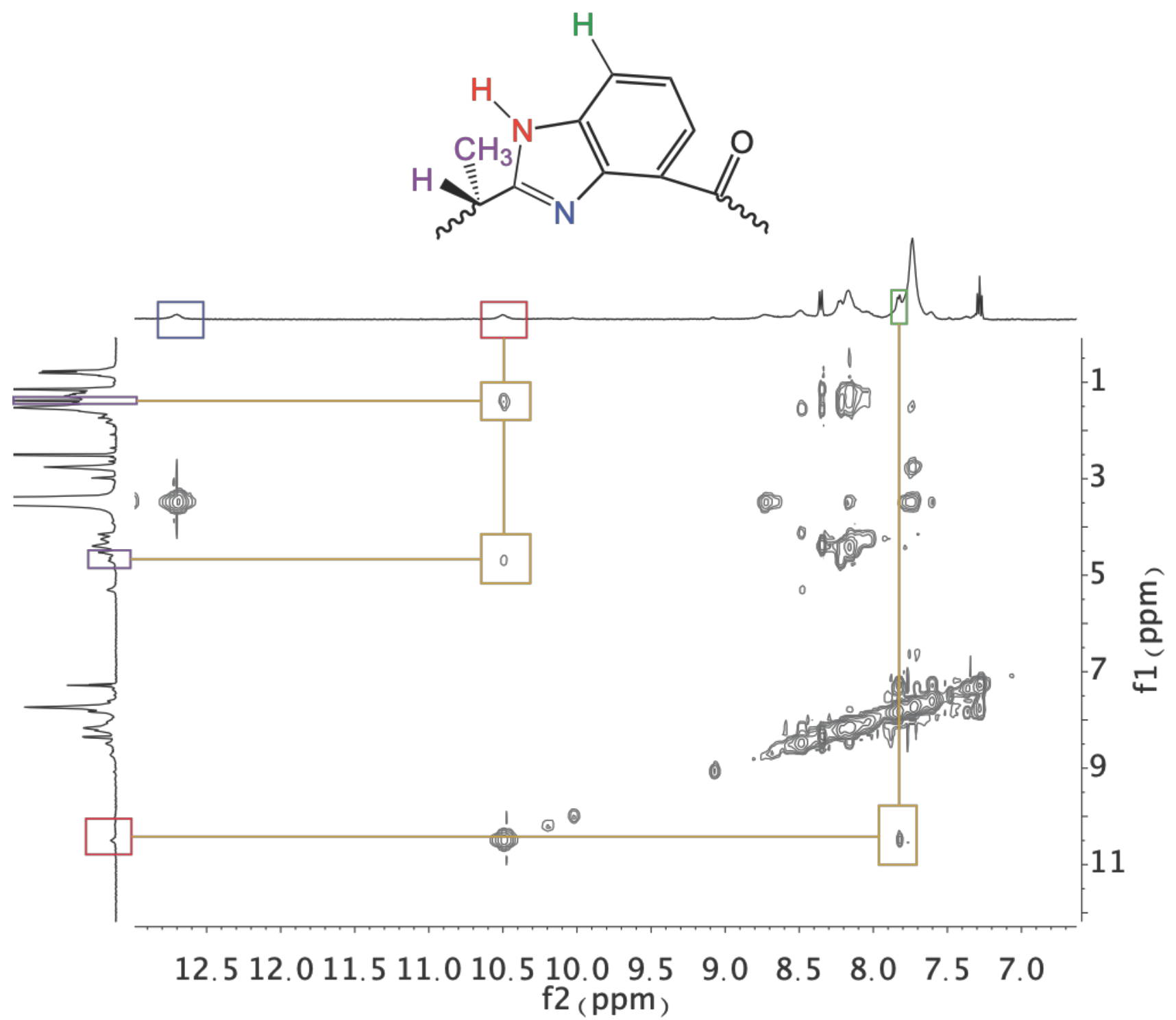

The NOESY spectrum aided in identifying and distinguishing between the two benzimidazole nitrogens. The cross peaks show that the benzimidazole nitrogen at $10.5 \mathrm{ppm}$ has near-space correlations with both an $\alpha$-carbon $(4.70 \mathrm{ppm})$, methyl group protons $(1.40 \mathrm{ppm})$ of alanine, and one of the aromatic protons (7.84 ppm). Because of the bond angles needed to cyclize the peptide, all side groups, $\alpha$-carbons, and aromatic protons point to the exterior of the ring. Therefore, it was concluded that the proton on the exterior of the cyclic peptide has the NMR shift of $10.50 \mathrm{ppm}$, while the interior proton, which had no observable correlations, has a shift of $12.69 \mathrm{ppm}$. It was noted that the interior proton shows a strong proton exchange with water molecules while the exterior proton does not. 


\subsection{HPLC Trace of Bzim-CP}

a) Analytical HPLC spectra of a blank (water) injection and purified Bzim-CP. The method used was as follows: $10-20 \% \mathrm{~B}$ over $8 \mathrm{~min}, 20-100 \% \mathrm{~B}$ over $1 \mathrm{~min}$, hold at $100 \% \mathrm{~B}$ for $4 \mathrm{~min}$, then $10 \% \mathrm{~B}$ for remainder. The spectra show that the obtained CPs are highly pure. Peaks seen starting around 10 min is likely contamination from the injector and appears equally in the blank and the sample. Spectra are slightly offset for clarity.

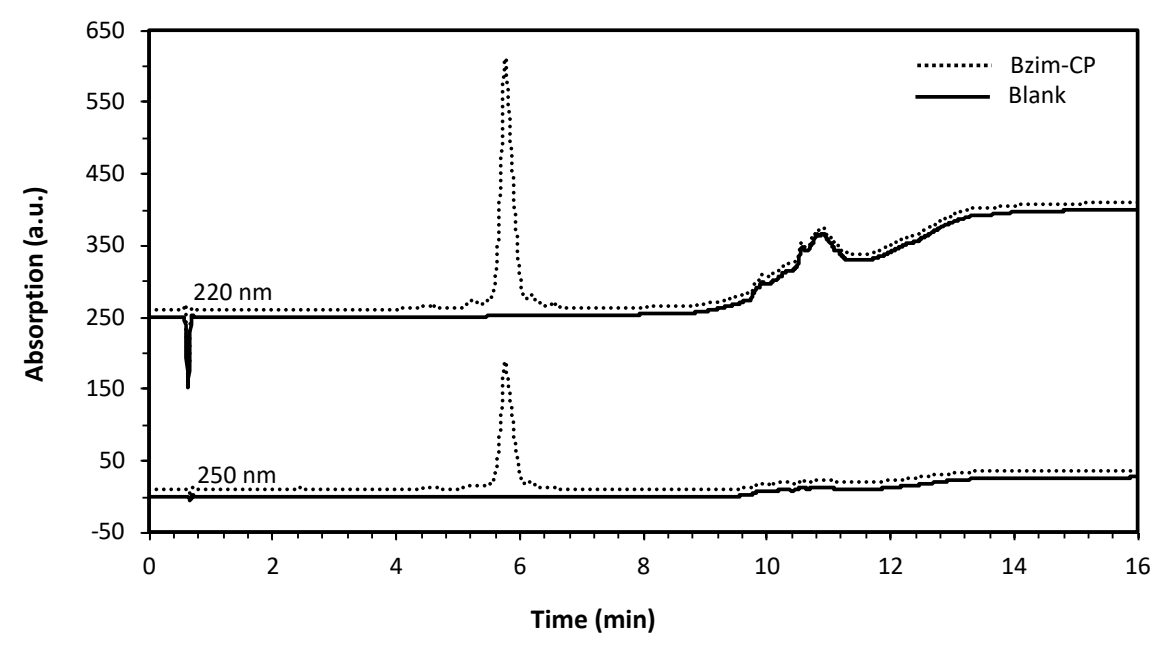

\subsection{MALDI-TOF, PEG conjugated Bzim-CP}

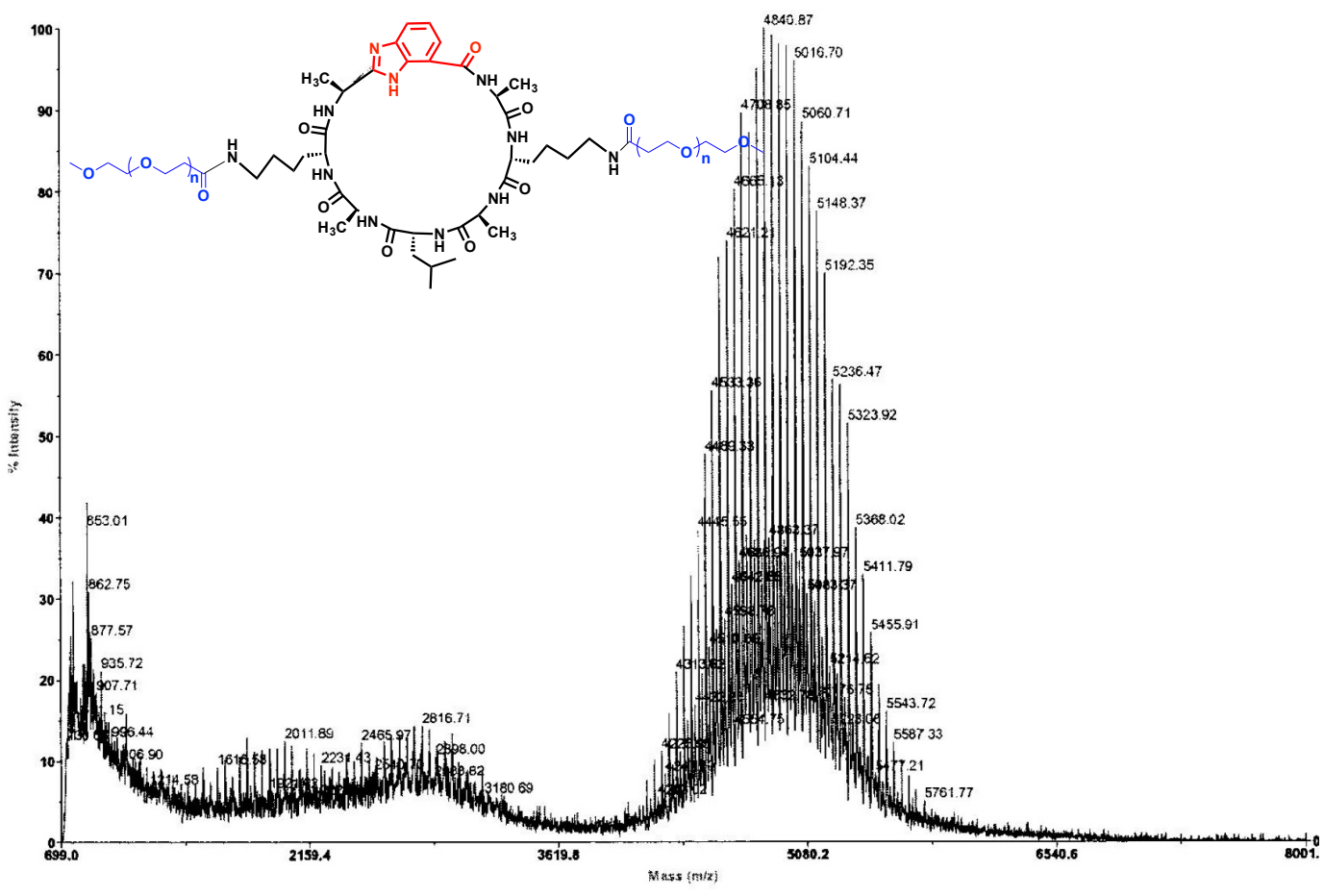

Polymer-conjugated Bzim-CP. Majority of CP has two 2000 Da PEG chains attached. Peak centered near $4840.87 \mathrm{~m} / \mathrm{z}$, which is consistent with the mass of the polymers and Bzim-CP. 


\subsection{UV-Vis of Controls}

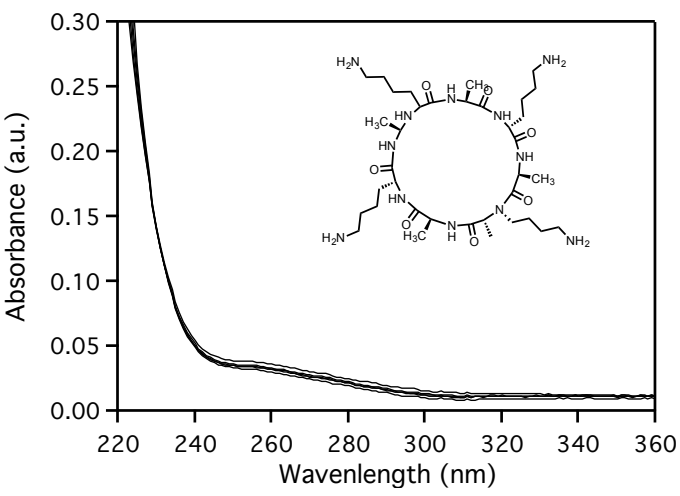

(a)

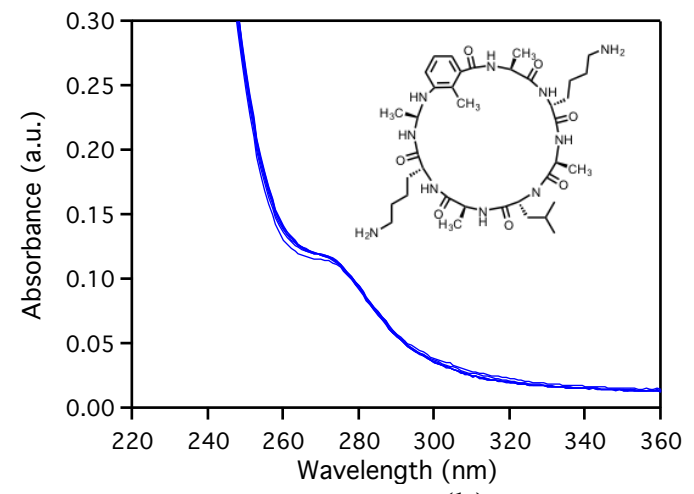

(b)

Change in the UV-Vis spectra spanning $\mathrm{pH}$ 2-13. Intensities were corrected for change in volume.

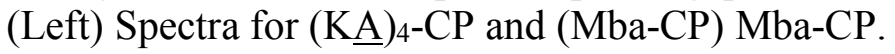

\subsection{Circular Dichroism with pH}

a)

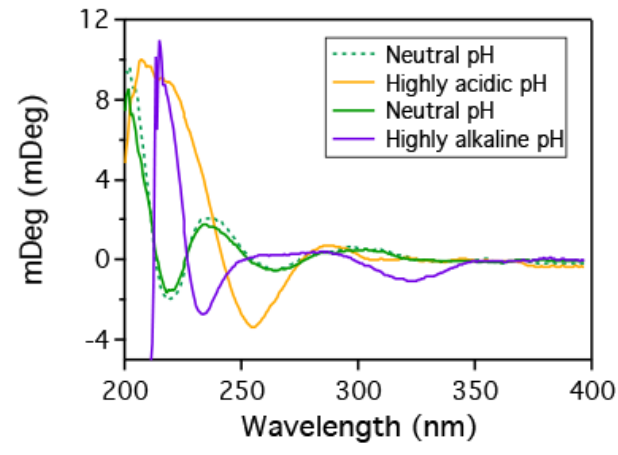

C)

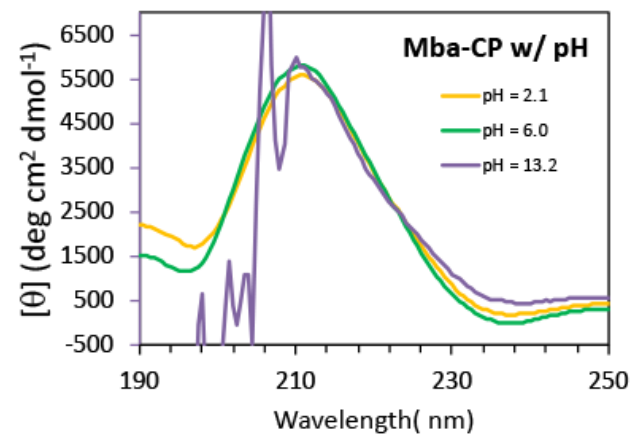

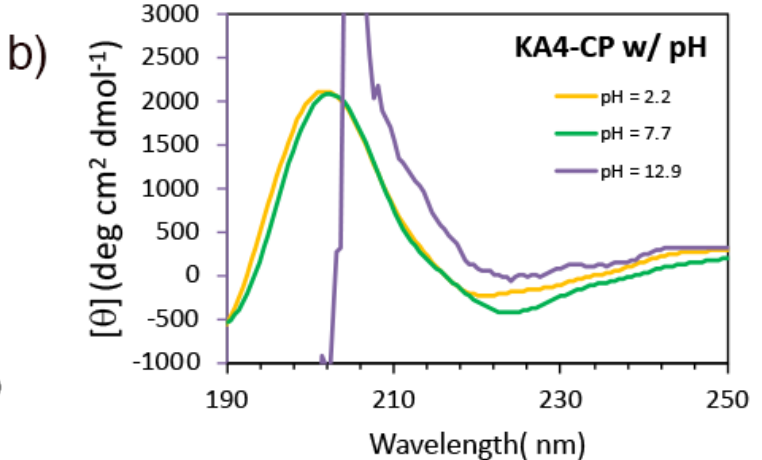

Wavelength( $\mathrm{nm})$

(a) Circular dichroism of Bzim-CP in water at different pHs (first image). Solution was acidified, then neutralized, and then alkalized. Changes in peak locations in the absorption region of the benzimidazole functionality with $\mathrm{pH}$ suggest changes in local environment due to charge states. Similar study done for

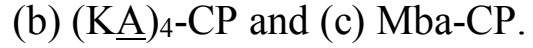




\subsection{Fluorescence Spectroscopy of Bzim-CP}

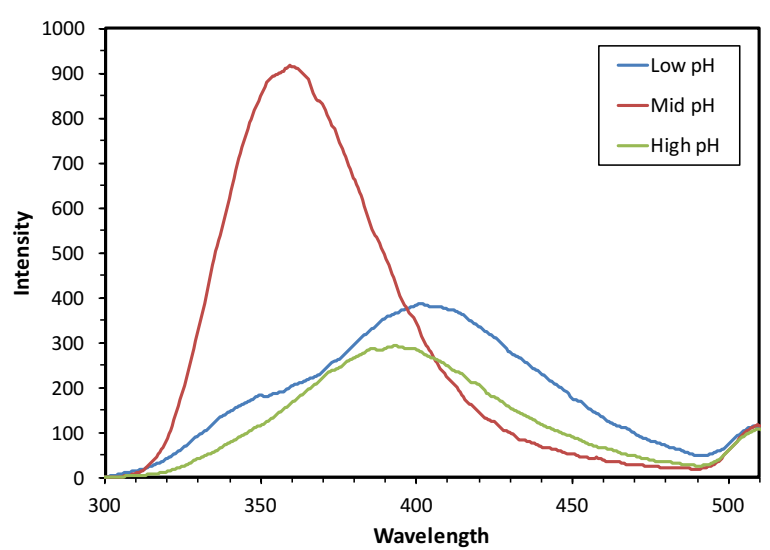

Fluorescence spectra of $10 \mu \mathrm{M}$ Bzim-CP in water at different pHs. Low $\mathrm{pH}$ was taken at pH 2.0; Medium at 7.4; and high at $\mathrm{pH}$ 12.7. In all cases, Bzim-CP was excited at $260 \mathrm{~nm}$.

\subsection{Thermal studies of solid state Bzim-CP by FTIR}
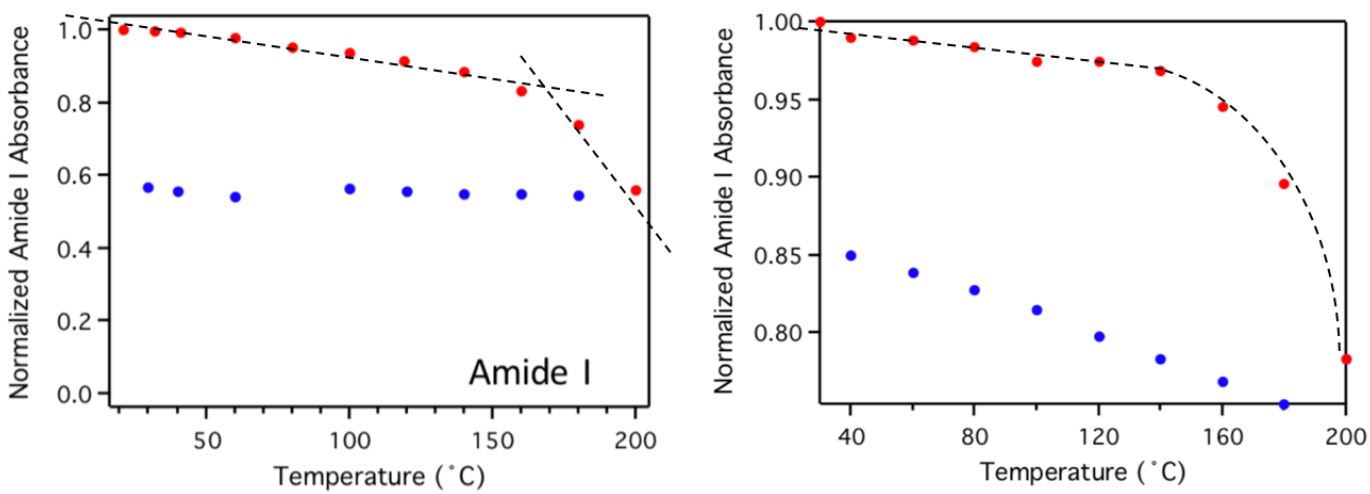

FTIR signal at $1632 \mathrm{~cm}^{-1}$ with increasing temperature. Normalized signals are shown. Left: Naked Bzim-CP, Right: Dried Bzim-CP-2PEG. Dotted lines are not fits; they are provided as visual guides.

Critical temperatures of disassembly was determined using FTIR. Both figures trace the Amide I band ( $\sim 1632 \mathrm{~cm}^{-1}, \mathrm{C}=\mathrm{O}$ stretching, perpendicular component) which is involved with hydrogen bonding between individual rings. Dotted lines are NOT fitted lines. Just visual guides. Critical temperature for disassembly are estimated to be around $170^{\circ} \mathrm{C}$ for the naked cyclic peptide and roughly $140-150^{\circ} \mathrm{C}$ for the pegylated cyclic peptide based on a sudden decrease in bond intensity. The difference between the naked and pegylated cyclic peptides is consistent with reports where exterior PEGylation weakens interring interactions and shortens nanotubes.

\subsection{Persistence length calculations}


Persistence lengths were calculated using the methods described in sources $\left[{ }^{1,2}\right]$. Images were imported into image processing open software, FIJI, (FIJI is Just) ImageJ. Lengths were measured by manually, using a straight line for end-to-end distances and a segmented line for the contour length. 30-50 nanotubes were measured for each type of processing done on the CPNs.

Briefly, the measured end-to-end distance $\mathrm{R}$ can be described by:

$$
<R^{2}>=\left(\frac{2}{\lambda^{2}}\right)[\lambda l-1+\exp (-\lambda L)]
$$

where $\lambda$ is the flexibility parameter and the inverse of the persistence length, $L$ is the contour length, and $l$ is the contour length of a segment along the nanotube.

The equation can be approximated for each individual nanotube as:

$$
R_{i}(\lambda) \approx \sqrt{\left(\frac{2}{\lambda^{2}}\right)\left[\lambda L_{i}-1+\exp \left(-\lambda L_{i}\right)\right]}
$$

Where $L_{i}$ is the measured value, and $R_{i}(\lambda)$ is the expected end-to-end distance for the given contour length and flexibility parameter.

From these equations, it is possible to find the most probable value of $\lambda$, by finding the value of $\lambda$ that minimizes the following equation. The persistent length is found by inversing the determined value

$$
\min S(\lambda)=\sum_{i}\left[R_{i}-R_{i}(\lambda)\right]^{2}
$$

$\ell_{\mathrm{p}}=1 / \lambda_{\text {most }}$ probable

\section{Bzim-CP nanotubes from DMF and acetonitrile were compared considering the following.}

The persistence length can be correlated to the bending modulus (or flexural force constant, $k_{f}$ ) and Young's modulus $(Y)$ as follows ${ }^{3}$ :

$$
l_{p}=\frac{k_{f}}{k_{B} T}=\frac{Y \eta}{k_{B} T}
$$

Where $\eta$ is the second moment of inertia. Because the observed structures are bundles of rather than individual tubes, $\eta$ is not straightforward to calculate. However, simplifying both sets of tubes as circular rods. Assuming it is a hollow tube, equation would change to Outer $\mathrm{d}^{4}-$ Inner $\mathrm{d}^{4}$

$$
\eta \propto d^{4}
$$

Simplifying the relations to:

$$
l_{p} \propto k_{f} \propto Y \eta \propto Y d^{4}
$$

Where $l_{p}$ and $d$ are calculated or measured values, each with relatively high error. From these values, the ratio of the Young's modulus of the nanotubes can be taken, with values close to 1 meaning the nanotubes in both images have the same stiffness. Doing so, we get:

$$
\frac{Y_{D M F}}{Y_{M e C N}}=.4
$$

However, given that there is high error associated with both measured values, one cannot rule out that the $\mathrm{Y}$ are truly different between the two materials and it is reasonable to assume that the difference in the observed curvature can be attributed to thickness differences and differences in moment of inertia.

\section{Molecular Dynamics Simulations}


To understand the structure of Bzim-CP and generate Figure 2 in the main text, molecular dynamics simulations were carried out. The simulations were performed on eight ring nanotubes using NAMD ${ }^{4}$ and visualized in $\mathrm{VMD}^{5}$. The peptide structures were parameterized with the CHARMM 36 force field ${ }^{6}$ while toluene was parameterized with CHARMM general force field ${ }^{7}$. The cyclic peptide ring structures were constructed as described in Alsina et al into a $\beta$-sheet stacking configuration ${ }^{8}$. The octapeptide structures were solvated in a $40 \AA$ x $40 \AA$ x $75 \AA$ box containing 640 toluene molecules packed under standard conditions. Periodic boundary conditions were applied. The solvated structures were minimized for 20 ps and equilibrated in the NPT ensemble for $2 \mathrm{~ns}$ at $1 \mathrm{~atm}$ and $298 \mathrm{~K}$ with no constraints. A Langevin damping coefficient of $5 \mathrm{ps}^{-1}$ was used to control the temperature. The Particle Mesh Ewald (PME) method was used to compute the long-range electrostatics, with a cutoff of $12 \AA$. When analyzing the equilibrium properties of the nanotube, only the last nanosecond of the simulation was considered.
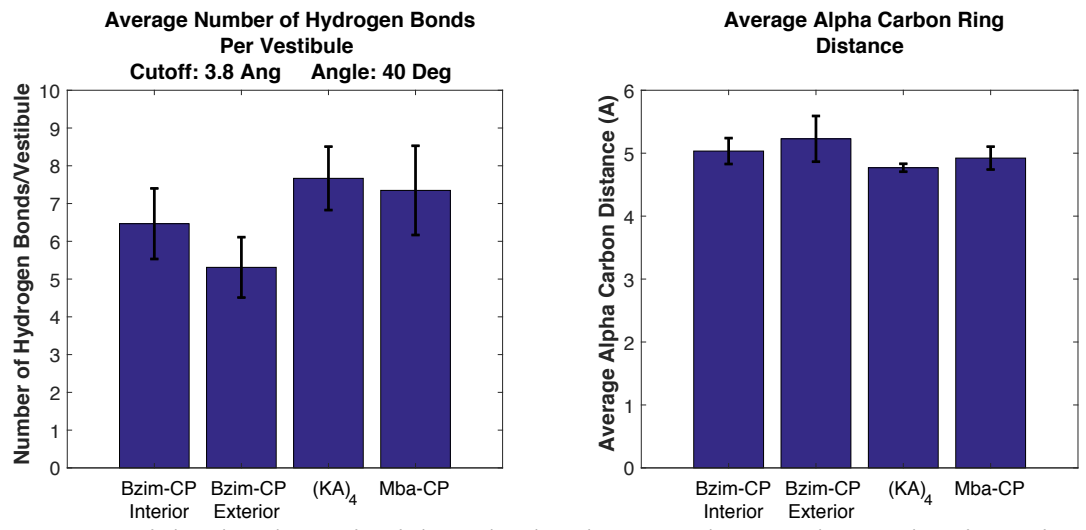

Comparison of Bzim-CP with the benzimidazole hydrogen located on the interior and exterior of the ring with prototypical $\mathrm{CPN},(\mathrm{KA})_{4}$ and methyl inserted Mba-CP. Simulations predict that both cases of Bzim-CP would form fewer inter-ring hydrogen bonds, and would be slightly farther apart compared to the other two.

\section{References}

1. Takebayashi, T.; Morita, Y.; Oosawa, F., Electron microscopic investigation of the flexibility of f-actin. Biochimica et Biophysica Acta (BBA) - Protein Structure 1977, 492 (2), 357-363.

2. Trachtenberg, S.; Hammel, I., The rigidity of bacterial flagellar filaments and its relation to filament polymorphism. Journal of Structural Biology 1992, 109 (1), 18-27.

3. Li, X.; Lehman, W.; Fischer, S., The relationship between curvature, flexibility and persistence length in the tropomyosin coiled-coil. Journal of Structural Biology 2010, 170 (2), 313-318.

4. Phillips, J. C.; Braun, R.; Wang, W.; Gumbart, J.; Tajkhorshid, E.; Villa, E.; Chipot, C.; Skeel, R. D.; Kalé, L.; Schulten, K., Scalable molecular dynamics with NAMD. Journal of Computational Chemistry 2005, 26 (16), 1781-1802.

5. Humphrey, W.; Dalke, A.; Schulten, K., VMD: Visual molecular dynamics. 1996; Vol. 14, pp $33-38$. 
6. $\quad$ Best, R. B.; Zhu, X.; Shim, J.; Lopes, P. E. M.; Mittal, J.; Feig, M.; MacKerell, A. D., Optimization of the Additive CHARMM All-Atom Protein Force Field Targeting Improved Sampling of the Backbone $\varphi, \psi$ and Side-Chain $\chi(1)$ and $\chi(2)$ Dihedral Angles. Journal of Chemical Theory and Computation 2012, 8 (9), 3257-3273. 7. Vanommeslaeghe, K.; Hatcher, E.; Acharya, C.; Kundu, S.; Zhong, S.; Shim, J.; Darian, E.; Guvench, O.; Lopes, P.; Vorobyov, I.; Mackerell, A. D., CHARMM general force field: A force field for drug-like molecules compatible with the CHARMM all-atom additive biological force fields. Journal of Computational Chemistry 2010, 31 (4), 671-690.

8. Alsina, M. A.; Gaillard, J.-F.; Keten, S., Conformational changes during permeation of Na+ through a modified cyclic peptide nanotube promote energy landscape roughness. Physical Chemistry Chemical Physics; Phys.Chem.Chem.Phys. 2016, 18 (46), 31698-31710. 